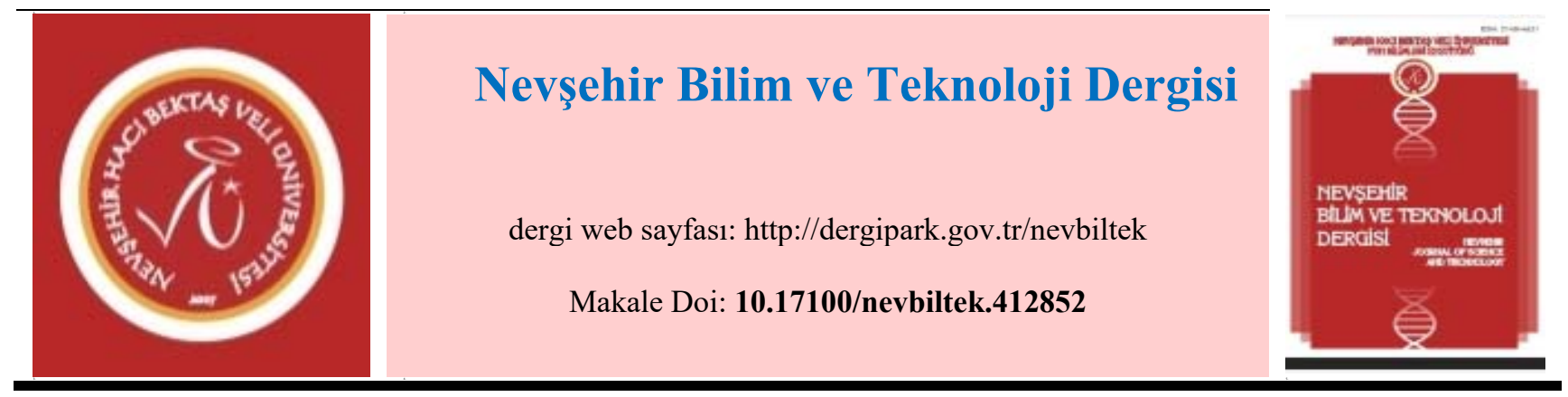

\title{
Günlenmeye Bağlı Oluşan Şekiller ve Bu Şekillerin Yerleşme Üzerine Etkileri, Gümüşhane Örneği
}

\author{
Ali İMAMOĞLU** Selim ERASLAN² Halil Çot $^{3}$ \\ ${ }^{1 *}$ Nevşehir Hacı Bektaş Veli Üniversitesi, Fen Edebiyat Fakültesi, Coğrafya Bölümü, NEVŞEHİR. \\ ORCID ID: 0000-0001-9197-1029
}

${ }^{2}$ Ondokuz Mayls Üniversitesi, Fen Edebiyat Fakültesi, Coğrafya Bölümü̈, SAMSUN

ORCID ID: 0000-0002-7574-6961

${ }^{3}$ Ondokuz Mayls Üniversitesi, Fen Edebiyat Fakültesi, Coğrafya Bölümü, SAMSUN

ORCID ID: 0000-0003-3713-7097

\begin{abstract}
Özet
Şehirler fiziki çevre şartlarına ve fonksiyonlarına göre büyür ya da küçülür. Araştırma litoloji ve günlenme hareketlerine bağlı olarak oluşan şekillerin oluşum ve gelişimlerini açıklanmıştır. Bu şekillerin şehrin yerleşme ve gelişme alanı üzerindeki etkisi incelenmiştir. Ayrıca bu şekillerin yerleşme üzerinde oluşturduğu baskı unsurları belirlenmiş bu probleme çözüm önerileri getirilmeye çalışılmıştır. Araştırmamızın sınırını oluşturan Hasanbey Mahallesi ve yakın çevresi, Gümüşhane şehir merkezinin kuzeydoğusunda Harşit çayı vadisinin kuzey yamaçlarında bulunmaktadır. Bu araştırmada saha ile ilgili literatür taraması arazi gözlem ve incelemeleri yapılmıştır. Saha ile ilgili çeşitli sayısal ve kartografik materyaller derlenmiş araştırma sahasının sayısal yükselti modeli, eğimi, bakısı, jeolojisi gibi yeni haritalar oluşturulmuştur. Elde edilen veriler bütüncül bir yaklaşımla değerlendirilerek jeomorfolojik süreç açıklanmaya çalışılmış ve bu sürecin yerleşme üzerindeki etkisi değerlendirilmiştir. Araştırma sahası yıllık ortalama $461.1 \mathrm{~mm}$ yağış alırken sahanın yıllık ortalama sıcaklığı $9.6^{\circ} \mathrm{C}$ dir. Araştırma sahası iklimi yarı kurak az nemli, mezotermal, su fazlası kış mevsiminde olan ve orta derecede deniz tesirine yakın iklim özellikleri gösterir. Araştırma sahası büyük toprak grupları haritasında kahverengi orman toprakları hâkim görülmektedir. Fakat sahanın çok şiddetli erozyona maruz kalması sebebiyle toprak örtüsü birçok yerinde ortadan kalkmıştır. Araştırma sahası sınırları içerisinde çok fazla bitki çeşitliliği bulunmamaktadır. Araştırma sahası anakayası granitlerden oluşur. Bu anakayaya Gümüşhane granitleri adı verilir. Bu anakaya günlenmeye karşı oldukça duyarlı gelişmiş çatlak sistemlerine sahiptir.

Araştırma sahanın planlaması yapılırken coğrafi özellikleri göz önünde bulundurulmalıdır. Özellikle eğimli yamaçlar üzerinde açılan yol kenarlarında önlemler alınmalıdır. Bazı bölgelere istinat duvarları yapılmalıdır. Riskli bulunan kesimlerde püskürtme betonlar dökülerek zemin stabil hale getirilmelidir.
\end{abstract}

Anahtar Kelimeler: Günlenme, Yerleşme, Gümüşhane Graniti

\section{Forms Due to weathering and Their Effects on Settlement, Gümüşhane Sample}

\section{Abstract}

Cities enlarged or dwindle according to physical environmental conditions and functions. Research explains the formation and development of forms, formed by lithology and weathering movements. The influence of these forms on the settlement and development area of the city has been examined. In adition to the pressure elements of these forms on the settlement have been determined and solution proposals submitted fort his problem. Hasanbey Mahallesi and its immediate surroundings, which constitute the border of our research is located east of Gümüşhane city center and right

*aliimamoglu@nevsehir.edu.tr 
hillshade of Harşit river. Field related literature review, field observations and reviews were done in this research. Related to the area digital and cartographic materials was compiled and the digital elevation model of the research area, the geology of the research area, the slope of the research new map have been created. The geomorphological process have tried to explain by evaluating the data that obtained. And the effect on this settlement was assessed. The research area receives an average annual precipitation of $461.1 \mathrm{~mm}$ and the average annual temperature of the area is 9.6 ${ }^{\circ} \mathrm{C}$. The climate of research area is shows semi-arid, slightly damp, mesotermal, over-water winter season and moderate to near-sea climate features characteristics. Brown forest soils are dominant in map whicw the large soil groups of research area. However, soil cover has risen in many places for the land was exposed to very severe erosion. There are not many plant varieties in the area of reserach. The reserach area has a structure is formed granite bedrock. This structure is called Gümüşhane granite. İt occurs that advanced crack systems that highly sensitive to weathering. The geographical features should be taken into consideration when planning the research area. Especially, measures should be taken in on the sides of the road on sloping hillshade. Retaining walls must be made in some areas. Structure must be stabilized that concrete extrusion worked in risky segments area.

Key Words: Weathering, Settlement, The Granite of Gümüşhane

\section{GíRiş}

İnsanoğlu yaşamının ilk gününden itibaren çeşitli ihtiyaçlara gereksinim duymuştur. Bu ihtiyaçların başında şüphesiz ki barınma gelmektedir. Çünkü insanoğlu yaşadığı çevrede önce güvenliğini sağlayacak, korunacak bir yer edinmelidir. $\mathrm{Bu}$ yüzden insanoğlu önce ağaç kovukları ve mağaralara daha sonra bulundukları doğal ortam şartlarına göre şekillenen barınaklara yerleşmişlerdir. İnsanlar yerleşik hayata geçişle birlikte bir arada yaşamaya başlamış ve toplu yerleşmeler ortaya çıkmıştır. Anadolu da tarihten bugüne kadar coğrafi şartların uygunluğu nedeniyle çeşitli yerleşmelere ve toplumlara ev sahipliği yapmıştır. Yaşadığımız coğrafya üzerinde birçok medeniyet kurulmuş, şehirler inşa edilmiş kimisi çeşitli sebeplerle yok olurken kimisi başka bölgelere taşınmak zorunda kalmıştır. Kimi şehirler ise varlığını hala kurulduğu alanda sürdürmektedir. En ilkelinden en gelişmişine kadar, her bir yerleşme biriminin varlığını sürdürebilmesi, fiziki çevre ile ilişkisindeki başarısına bağlı olmuştur [1].

Şehirler fiziki çevre şartlarına, fonksiyonlarına göre bazen büyüyüp gelişirken bazen de çeşitli sebeplerle küçülmüştür. Bazı şehirlerde beşeri ya da fiziki sebeplerle yer değiştirmek zorunda kalmıştır. Şehirlerin gelişiminin ise yatay ya da dikey olarak ya da her iki şekilde de olduğu görülmektedir.

$\mathrm{Bu}$ çalışmada litolojinin günlenme hareketlerine bağlı olarak gelişimi açıklanmaya çalışılmış ve sürecin şehrin yerleşme ve gelişme alanı üzerindeki etkisi üzerinde durulmuştur. Ayrıca günlenmeye bağlı oluşan şekillerin yerleşme üzerinde oluşturduğu baskı unsurları belirlenerek çözüm önerileri getirilmeye çalışılmıştır.

Tor şekilleri, bazı anakayaların günlenme süreçlerine bağlı olarak aşındığı sahalarda aşınım sonrasında ortaya çıkan çatlaklı tümsek şekillerdir. Tor topografyaları ile ilgili yapılan eski çalışmalarda tor oluşumunda temel belirleyici faktörün kuraklık olduğu savunulurken, son yıllarda yapılan çalışmalarda daha farklı iklim şartlarında da torların gelişebildiği anlaşılmıştır [2-5].

\section{MATERYAL VE YÖNTEM}

\subsection{MATERYAL}

Gümüşhane ili Karadeniz Bölgesi’nin Doğu Karadeniz Bölümü’nde yer almaktadır. Doğusunda Bayburt, batısında Giresun, kuzeyinde Trabzon ve güneyinde Erzincan illeri bulunmaktadır. İl merkezi Harşit Çayı üzerinde yaklaşık 15 km boyunca vadinin yerleşmeye uygun kısımlarında dağılış göstermektedir. Araştırmamızın sınırını oluşturan Hasanbey Mahallesi ve yakın çevresi Gümüşhane şehir merkezinin kuzeydoğusunda Harşit çayının kuzey yamaçlarında bulunmaktadır. Araştırma sahası tor şekillerinin gelişme gösterdiği tepelik alan, yamaçlar ve yerleşmenin nispeten daha yoğun olduğu Hasanbey mahallesinin merkezini içine almaktadır. 


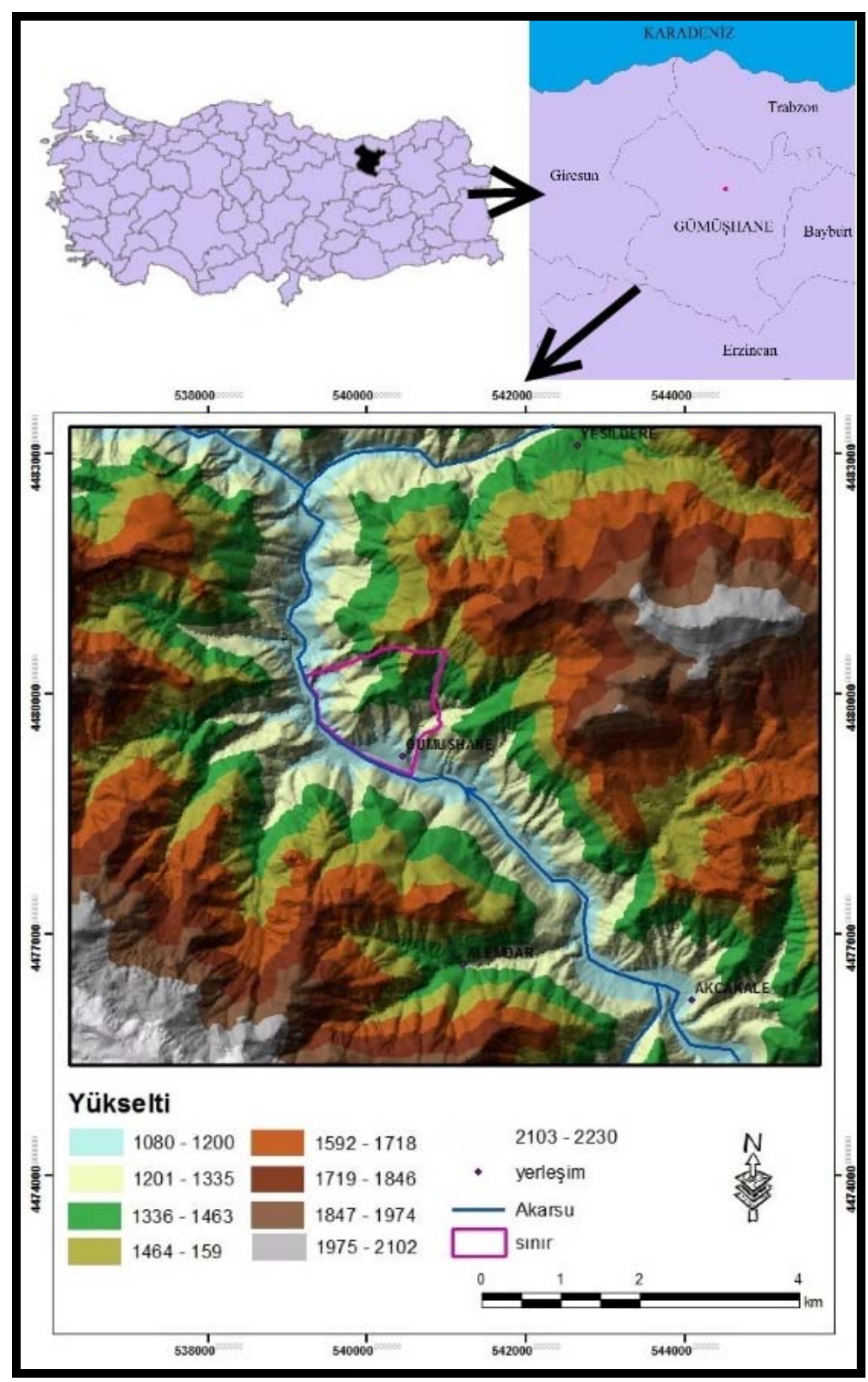

Şekil 1. Araştırma sahası lokasyon haritası.

\subsection{YÖNTEM}

Araştırmada saha ile ilgili literatür taraması yapılmıştır. Arazi gözlem ve incelemeleri yapılmış, bu sırada sahadan çeşitli örnekler alınmıştır. Sahadan alınan bitki örnekleri Ondokuz Mayıs Üniversitesi Biyoloji Bölümünde, uzman kişiler ile birlikte incelenmiş ve bitkiler tür bazında belirlenmiştir. Saha içerisinde farklı noktalardan alınan toprak örnekleri ise Ondokuz Mayıs Üniversitesi Ziraat Fakültesi Toprak Bölümü laboratuvarında incelenmiş ve tekstür sınıfı ortaya konulmuştur. Ayrıca sahanın doğal ortam özelliklerini ve bazı beşerî özelliklerini daha iyi açıklayabilmek için sahaya ait çeşitli sayısal ve kartografik materyaller derlenmiştir. Araştırma sahasının 1:25.000 ölçekli topografya ve jeoloji haritaları kullanılarak sahaya ait sayısal yükselti modeli, eğim, bakı, jeoloji gibi yeni haritalar oluşturulmuştur. $\mathrm{Bu}$ haritaların oluşturulması aşamasında ArcGIS v9.3 programından yararlanılmıştır.

Çalışma sahasının iklim özelliklerini belirlemek için Gümüşhane meteoroloji istasyonuna ait rasat verileri kullanılmıştır. 
Elde edilen veriler bütüncül bir yaklaşımla değerlendirilerek litolojik gelişim açıklanmaya çalışılmış ve günlenmenin yerleşme üzerindeki etkisi değerlendirilmiştir.

\section{BULGULAR}

\subsection{Doğal Ortam Özellikleri}

\subsection{1. İklim}

Araştırma sahasının iklim özellikleri Gümüşhane meteoroloji istasyonu rasat verileri kullanılarak belirlenmiştir. Çalışma alanı ve yakın çevresine ait yağış ve sıcaklık haritaları enterpolasyon yöntemiyle yapılımıştır. Araştırma sahası yıllık ortalama $461.1 \mathrm{~mm}$ yağış alırken sahanın yıllık ortalama sıcaklığı $9.6^{\circ} \mathrm{C}$ dir.

Gümüşhane'de yılın en soğuk ayı Ocaktır $\left(-1.6^{\circ} \mathrm{C}\right)$. En sıcak aylar ise Temmuz ve Ağustos aylarıdır $\left(20.2^{\circ} \mathrm{C}, 20.1^{\circ} \mathrm{C}\right)$. Yılın altı ayında (Kasım, Aralık, Ocak, Şubat, Mart, Nisan) ortalama sıcaklıklar $10^{\circ} \mathrm{C}$ 'nin altındadır. Özellikle sıcaklıkların $0^{\circ} \mathrm{C}$ 'nin altına düştüğü Ocak ve Şubat aylarında don olayları olmaktadır. Don olayları ile bağlantılı olarak fiziksel parçalanma bu aylarda hızlanmaktadır. Bu da araştırma sahasının morfolojik değişimini hızlandırır. Araştırma sahası uzun yıllar aylık yağış ortalamalarına baktığımızda en düşük yağış miktarının Temmuz (11.9 mm) ayında olduğu, en yüksek yağı̧ miktarının Mayıs $(67.4 \mathrm{~mm}$ ) ayında olduğu görülmektedir (Tablo 1). Araştırma sahasına en fazla yağış ilkbahar mevsiminde düşmektedir. $\mathrm{Bu}$ da bahar aylarında yağışlara bağlı oluşabilecek tehlikelerin daha fazla olabileceğini göstermektedir.

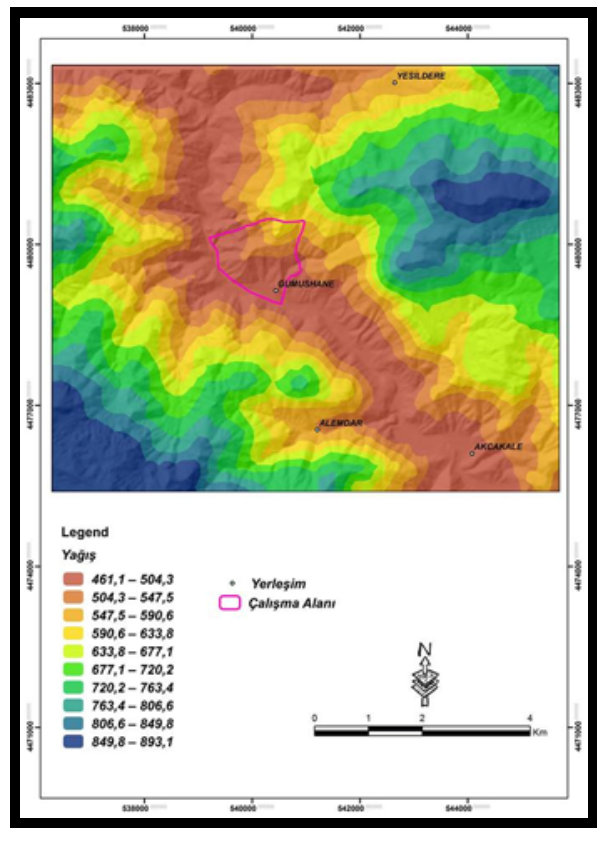

Şekil 2. Araştırma sahası yağış dağılış haritası.

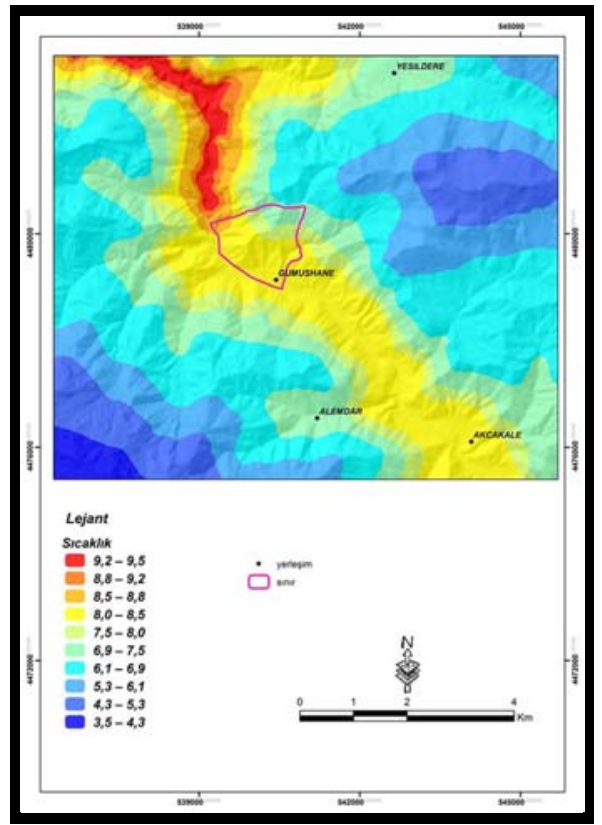

Şekil 3. Araştırma sahası sıcaklık dağılış haritası. 
Tablo 1: Gümüşhane Meteoroloji İstasyonuna ait bazı rasat değerleri (Yükseklik: $1219 \mathrm{~m}$, Enlem: $40^{\circ} \mathrm{K}$, Boylam: $39^{\circ} \mathrm{D}$ ).

\begin{tabular}{|c|c|c|c|c|}
\hline $\begin{array}{l}\text { Gümüşhane } \\
\text { (1970-2012) }\end{array}$ & $\begin{array}{l}\text { Ort. Sicaklık } \\
\left(\mathrm{C}^{\circ}\right)\end{array}$ & $\begin{array}{l}\text { Ort. Yağış } \\
(\mathrm{mm})\end{array}$ & $\begin{array}{l}\text { Ort. Karlı } \\
\text { Gün Sayısı }\end{array}$ & $\begin{array}{l}\text { Ort. Karla } \\
\text { Ört. Gün }\end{array}$ \\
\hline Rasat Süresi (Yıl) & 42 & 42 & 42 & 42 \\
\hline Ocak & -1.9 & 33.7 & 11 & 21.1 \\
\hline Şubat & -0.6 & 32.9 & 10.1 & 19.8 \\
\hline Mart & 3.7 & 41.4 & 8.0 & 7.5 \\
\hline Nisan & 9.4 & 62.3 & 2.3 & 0.6 \\
\hline Mayıs & 13.5 & 67.4 & 0.2 & - \\
\hline Haziran & 17.1 & 46 & - & - \\
\hline Temmuz & 20.2 & 11.9 & - & - \\
\hline Ağustos & 20.1 & 13.5 & - & - \\
\hline Eylül & 16.6 & 21.5 & - & - \\
\hline Ekim & 11.4 & 47 & 0.5 & 0.1 \\
\hline Kasım & 4.8 & 44.3 & 4.2 & 3.5 \\
\hline Aralık & 0.3 & 39.2 & 8.8 & 14.1 \\
\hline Yillık & 9,6 & 461.1 & 44.1 & 66.7 \\
\hline
\end{tabular}

Kaynak: DMİGM Gümüşhane Meteoroloji İstasyonu yayımlanmamış döküm cetvelleri.

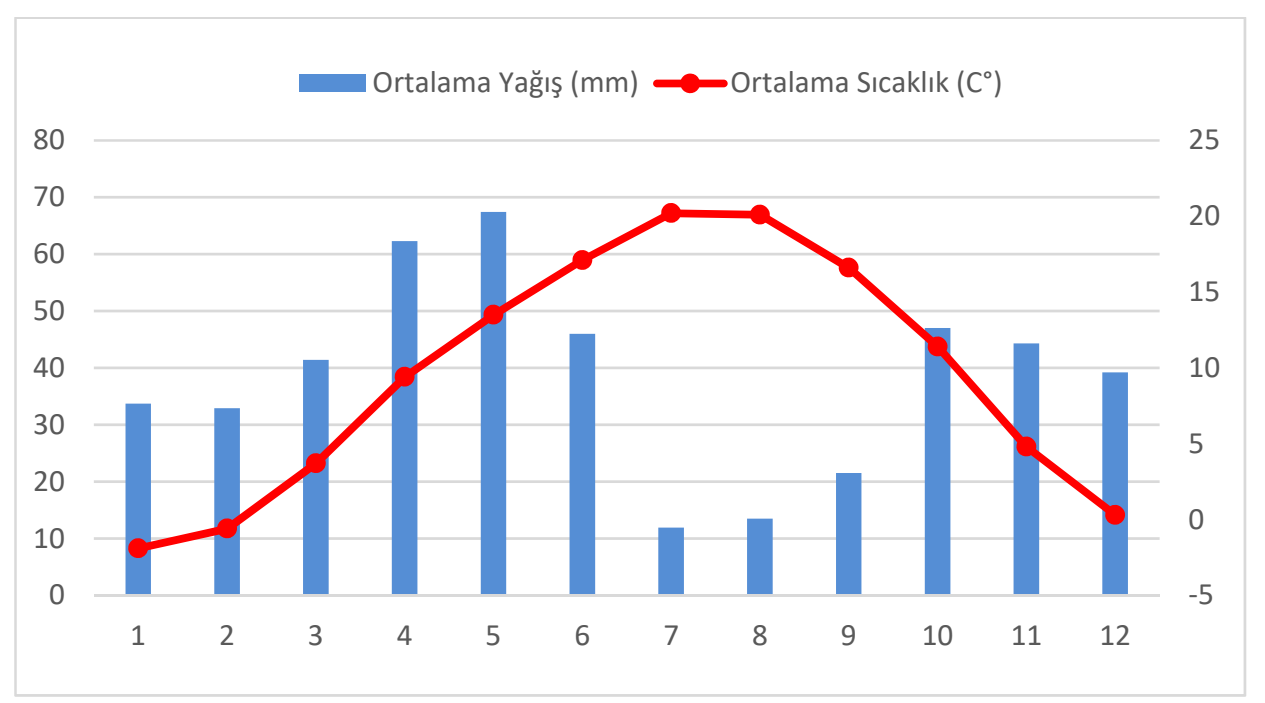

Şekil 4. Gümüşhane meteoroloji istasyonuna ait ortalama sıcaklık ve yağış grafiği.

Araştırma sahanın iklim sınıfı thorntwaite metoduna göre belirlenmiştir. Bu amaçla öncelikle araştırma sahasına ait su bilançosu hazırlanmıştır. Su bilançosu grafiğine göre buharlaşma eğrisi Nisan ayı sonlarından Ekim ayı ortalarına kadar yağış eğrisinden yüksektir. Nisan sonlarından Temmuz ortalarına kadar birikmiş su kullanılmıştır. Temmuz ortalarından Ekim ortalarına kadar kuraklık hakimdir. Araştırma sahası iklimi C1,B'1,s,b'3 harfleriyle ifade edilen; yarı kurak az nemli, mezotermal, su fazlası kış mevsiminde olan ve orta derecede deniz tesirine yakın iklim özellikleri gösterir. 
Tablo 2: Thorntwaite'e göre araştırma sahası su bilançosu.

\begin{tabular}{|c|c|c|c|c|c|c|c|c|c|c|c|c|c|}
\hline $\begin{array}{l}\text { Gümüşhane } \\
(1970-2012)\end{array}$ & 1 & 2 & 3 & 4 & 5 & 6 & 7 & 8 & 9 & 10 & 11 & 12 & Yillık \\
\hline Sıcaklık & $-1,9$ & $-0,6$ & 3,7 & 9,4 & 13,5 & 17,1 & 20,2 & 20,1 & 16,6 & 11,4 & 4,8 & 0,3 & 9,55 \\
\hline Sıcaklık İndisi & - & - & 0,63 & 2,60 & 4,50 & 6,44 & 8,28 & 8,22 & 6,15 & 3,48 & 0,94 & 0,01 & 41,25 \\
\hline $\begin{array}{l}\text { Düzeltilmemiş } \\
\text { PE }\end{array}$ & - & - & 14 & 40 & 60 & 80 & 100 & 98 & 75 & 52 & 19 & 1,2 & \\
\hline $\begin{array}{l}\text { Düzeltilmiş } \\
\text { PE }\end{array}$ & - & - & 14,4 & 44,4 & 74,4 & 100 & 127 & 115,6 & 78 & 49,9 & 15,7 & 0,9 & \\
\hline$\overline{\text { Yağı̆ıs }}$ & 33,7 & 32,9 & 41,4 & 62,3 & 67,4 & 46,0 & 11,9 & 13,5 & 21,5 & 47,0 & 44,3 & 39,2 & 461,1 \\
\hline $\begin{array}{l}\text { Bir. Su. Ay. } \\
\text { Değ. }\end{array}$ & 32,8 & 0,3 & - & - & 7 & 54 & 39 & - & - & - & 28,5 & 38,2 & \\
\hline Birikmiş Su & - & - & 14,4 & 44,4 & 74,4 & 100 & 50,9 & 13,5 & 21,5 & 47,0 & 15,7 & 0,9 & \\
\hline $\begin{array}{l}\text { Gerçek } \\
\text { Evapotransp. }\end{array}$ & - & - & - & - & - & - & 76,1 & 102,1 & 56,5 & 2,92 & - & - & \\
\hline Su Noksanı & 33,7 & 32,9 & 26,9 & 17,9 & - & - & - & - & - & - & 28,5 & 38,2 & \\
\hline Su Fazlası & 29,9 & 30,8 & 28,9 & 23,4 & 11,7 & 5,8 & 2,9 & 1,4 & 0,7 & 0,3 & 14,2 & 26,2 & \\
\hline$\overline{\mathbf{A k} \text { Iş }}$ & - & - & 1,87 & 0,40 & $\begin{array}{c}- \\
0,09\end{array}$ & $\begin{array}{c}- \\
0,54\end{array}$ & $\begin{array}{c}- \\
0,90\end{array}$ & $-0,88$ & $\begin{array}{c}- \\
0,72\end{array}$ & $\begin{array}{c}- \\
0,05\end{array}$ & 1,80 & 39,32 & \\
\hline $\begin{array}{l}\text { Nemlilik } \\
\text { Oranı }\end{array}$ & 1 & 2 & 3 & 4 & 5 & 6 & 7 & 8 & 9 & 10 & 11 & 12 & Yillik \\
\hline
\end{tabular}

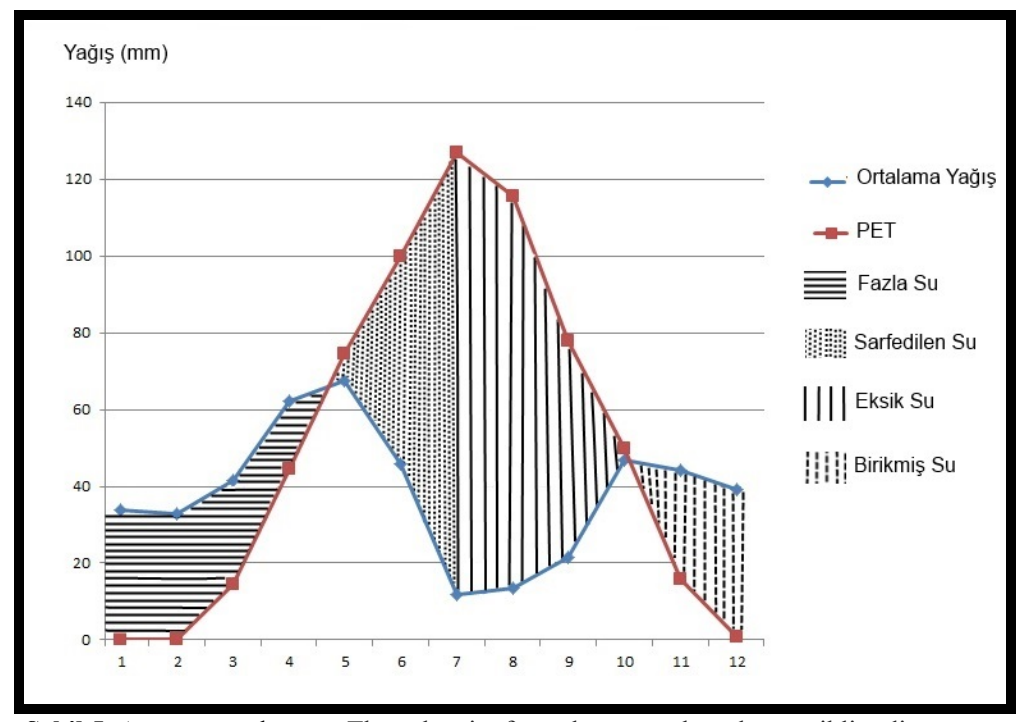

Şekil 5. Araştırma sahasının Thornthwaite formülüne göre hazırlanmış iklim diyagramı.

Araştırma sahasının iklim verileri bir bütün olarak değerlendirildiğinde; sahada yaklaşık üç aylık kurak bir devrenin olduğu, genelde nemli bir iklimin hüküm sürdüğü sonucuna varılmıştır (Tablo 2, Şekil 5). 


\subsubsection{Toprak}

Araştırma sahası toprak özellikleri bakımından çok gelişme gösterememiştir. Litolojik olarak anakayanın parçalanmaya ve toprak oluşumuna uygun özellik göstermesine rağmen toprak gelişmemiştir. Bunun başlica sebepleri arasında bitki örtüsünden yoksunluk, eğim değerlerinin yüksek olması gösterilebilir. Yüzeyin açık olması ve eğimin yüksek olması sebebiyle günlenme süreçlerine bağlı oluşan materyal ortamdan uzaklaştırılmaktadır. Çevresine göre nispeten daha az eğimli alanlarda kaba unsurlu materyaller arasında yine kaba tekstürlü topraklar bulunmakla birlikte horizonlaşma gösteremeyecek kadar sığ örtülerdir. Çalışma alanı içerisinde bulunan toprak varlığı ise evlerin bahçelerinde duvarlarla çevrilerek oluşturulmuş yapay alanlarda görülmektedir. Arazi araştırması sırasında evlerden bazılarının bahçelerine kamyonetlerle toprak getirdiği bilgisine ulaşılmıştır.

Araştırma sahası büyük toprak grupları haritasına baktığımızda Kahverengi orman topraklarının hâkim olduğu görülmektedir. Fakat sahanın çok şiddetli erozyona maruz kalması sebebiyle toprak örtüsü birçok yerinde ortadan kalkmış ve çıplak anakaya görülmektedir. Bu da günlenme etkisini ve şekil oluşumunu tetikleyen faktörlerden birisidir.

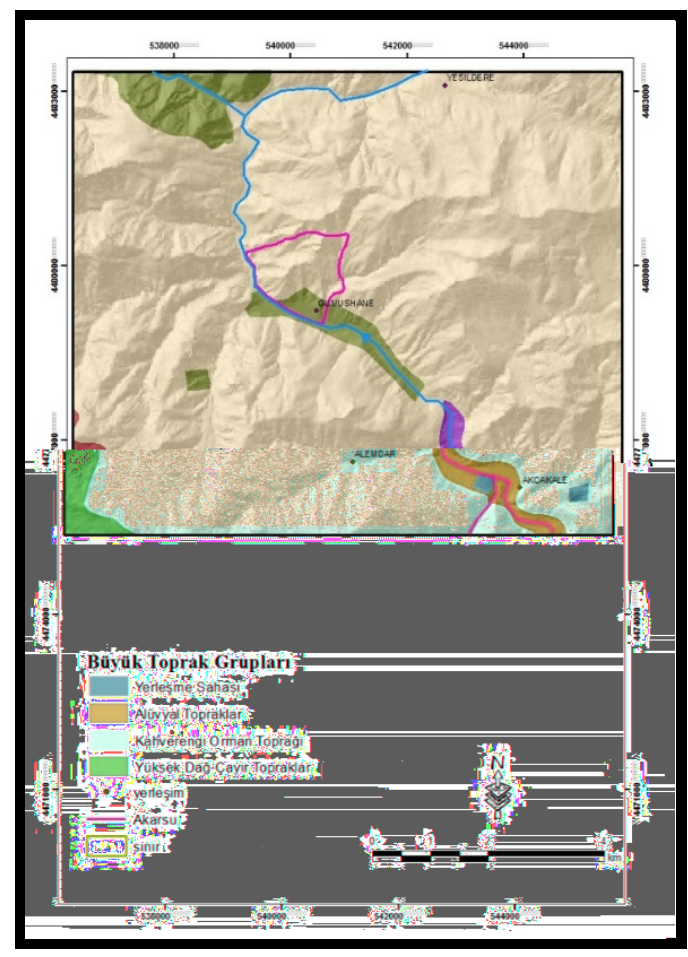

Şekil 6. Araştırma sahası büyük toprak grupları haritası.

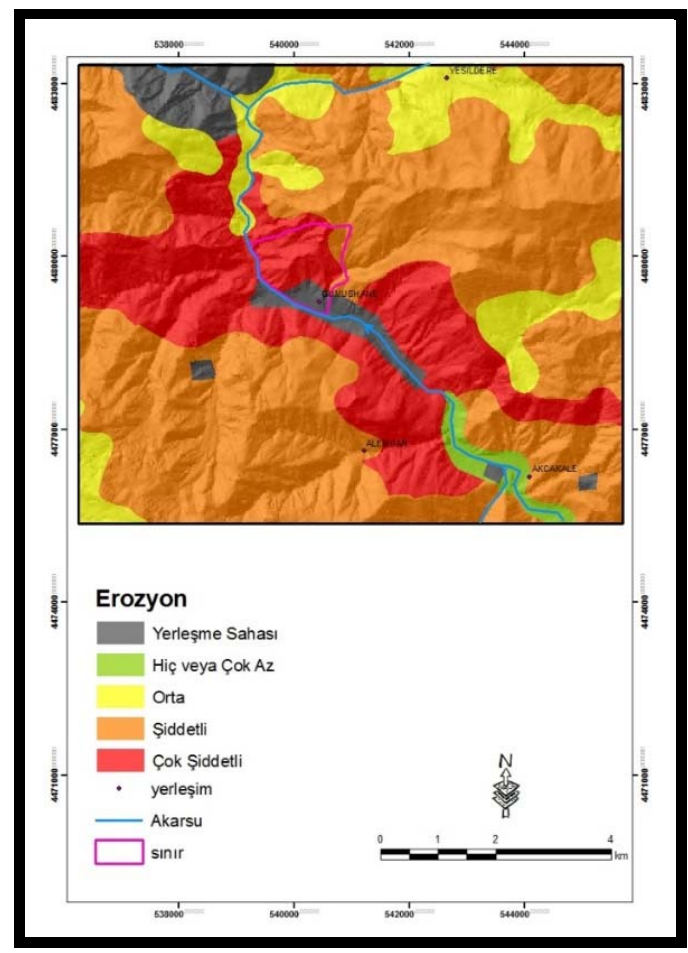

Şekil 7. Araştırma sahası erozyon haritası. 


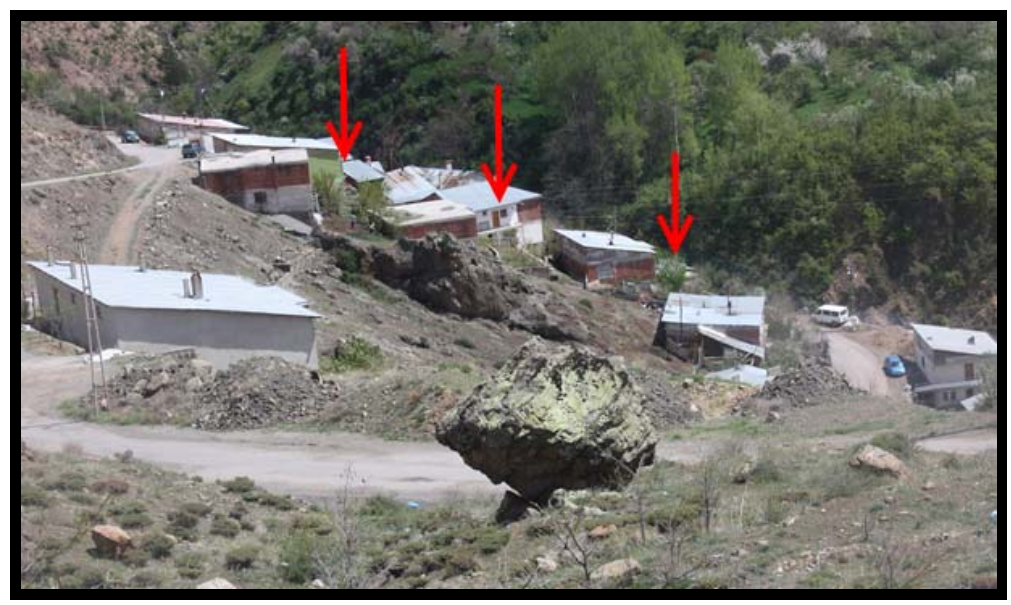

Foto 1. Evlerin bahçelerine taşınarak getirilen topraklar.

\subsubsection{Bitki Örtüsü}

Gümüşhane şehri bitki örtüsü bakımından Avrupa-Sibirya floristik bölgesinin kolşik provensinde yer alır. Bununla birlikte araştırma sahası sınırları içerisinde çok fazla bitki çeşitliliği bulunmamaktadır. Gümüşhane ili yamaçlarında görülen bitki asimetrisine baktığımızda bitki örtüsünün tahrip edildiği düşünülmektedir. Eski kaynakların araştırılması sırasında da şehrin bir maden şehri olduğu, 1800'lü yılların ortalarında yöre ormanlarının tükenmesi sonucu yakıt sıkıntısının oluştuğu söylenmektedir [6]. Ayrıca araştırma alanı içerisinde bol miktarda bulunan geven (Astragalus sp.) bitkisi tahribat alanlarına yerleşen ikincil bir türdür (Foto 2). Araştırma sahasında otsu bitkiler kayalardaki küçük çatlaklarda ya da çok küçük alanlardaki toprak parçalarına tutunmuş şekilde karşımıza çıkmaktadır. Sahada genellikle otsu bitkiler bulunmakla birlikte kuşburnu (Rosa canina) gibi çalı formunda odunsu bitkilerde bulunmaktadır. Harşit çayına doğru indikçe ve vadi içlerine girdikçe ise kavak, akasya, alıç gibi bitki türleri bulunmaktadır.

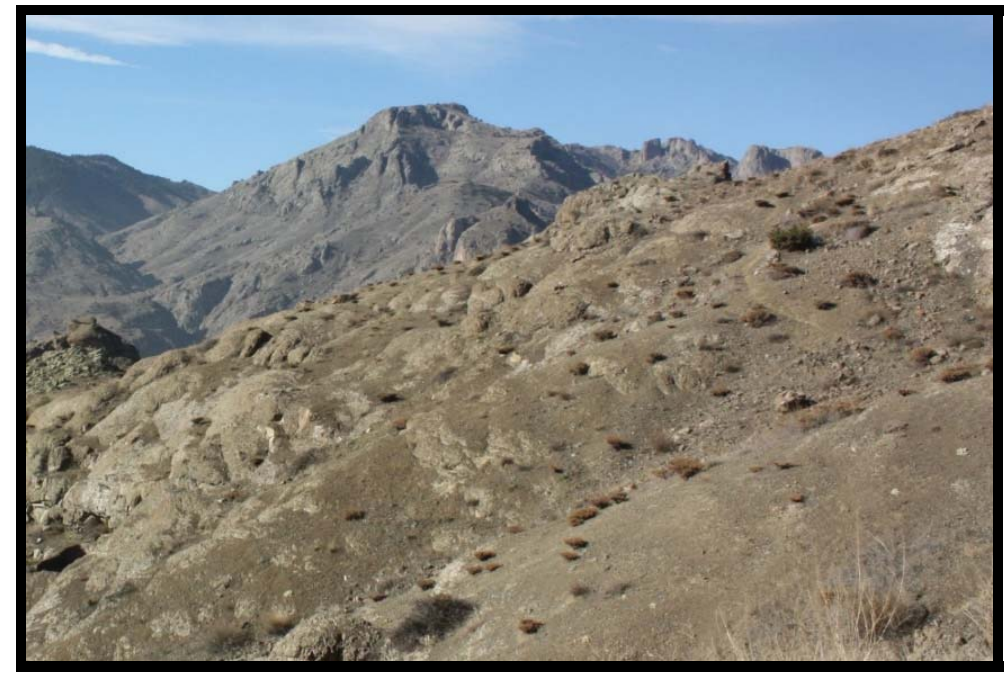

Foto 2. Araştırma sahasında yayılış gösteren Astragalus sp. 


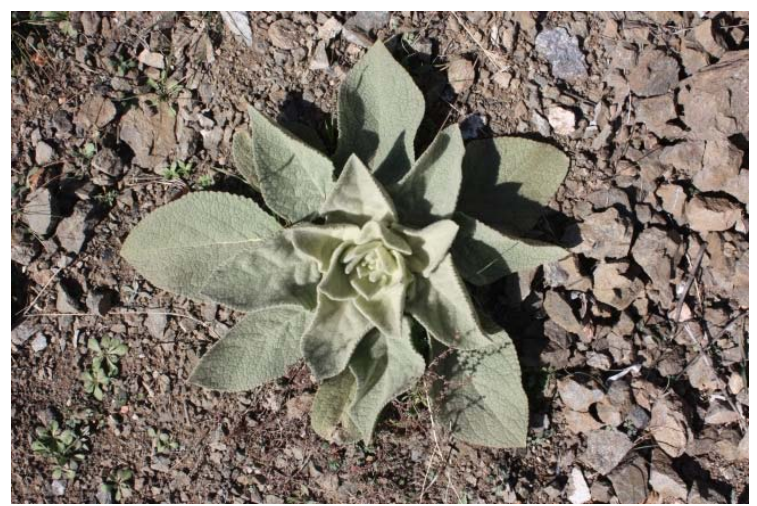

Foto 3. Sığ toprak üzerinde oluşan otsu bitkiler.

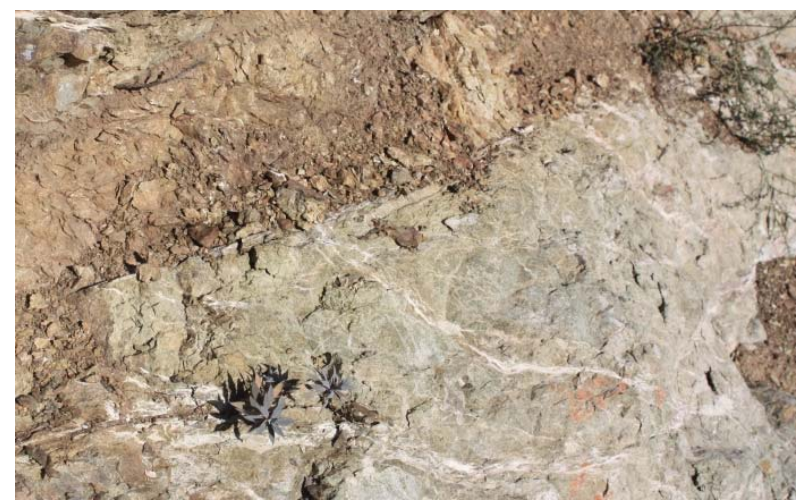

Foto 4. Anakaya üzerindeki çatlaklarda yetişen otsu bitkiler.

\subsubsection{Litoloji}

Gümüşhane ili merkez sınırlarında yer alan çalışma alanı, Anadolu’nun büyük tektonik birliklerinden Pontid tektonik birliği içinde yer alır [7].

Araştırma sahası yakın çevresinde Tersiyer, Mesozoyik ve Paleozoyik yaşlı araziler bulunmaktadır (Şekil 8). Litostratigrafi birimi esasına göre inceleme yapılan bölgede en yaşlı birim, temeli oluşturan Paleozoyik yaşlı Gümüşhane Granitleri’dir ve homojen görünümlü Gümüşhane Granitleri petrografik özelliklerine dayanılarak değişik fasiyeslere ayırtlanmıştır [8-9]. Araştırma sahasının tamamı Gümüşhane Granitlerinden oluşmaktadır.

İnceleme alanındaki yüzeylemelerde fasiyeslerin yüzeye yakın kesimlerde oluşmuş piromerid ve derinlerde oluşmuş granitlerin varlığı saptanmış, her iki fasiyeste gelişmiş kayaçlarda taneli doku egemen olup kristaller yer yer 5mm'ye ulaşır [10].

Yaşı: inceleme alanında birimi, taban konglomerasıyla üstleyen, en yaşlı kayaçlar Liyas sürecinde gelişmiş Zimonköy formasyonu'na aittir. Bu veri Gümüşhane granitinin Liyas öncesinde geliştiğini gösterir. Gümüşhane yöresinde, Gümüşhane granitine ait toplam kurşun yöntemiyle 298-338 milyon yıl yaş bulmuştur [10].

Torlar ile ilgili yapılan çalışmalarda genellikle tor oluşumunda anakayanın daha belirleyici olduğu ve özellikle granitler üzerinde geliştikleri kabul edilmiştir [11,5]. 
Nevşehir Bilim ve Teknoloji Dergisi (2018), 7(1) 83-99

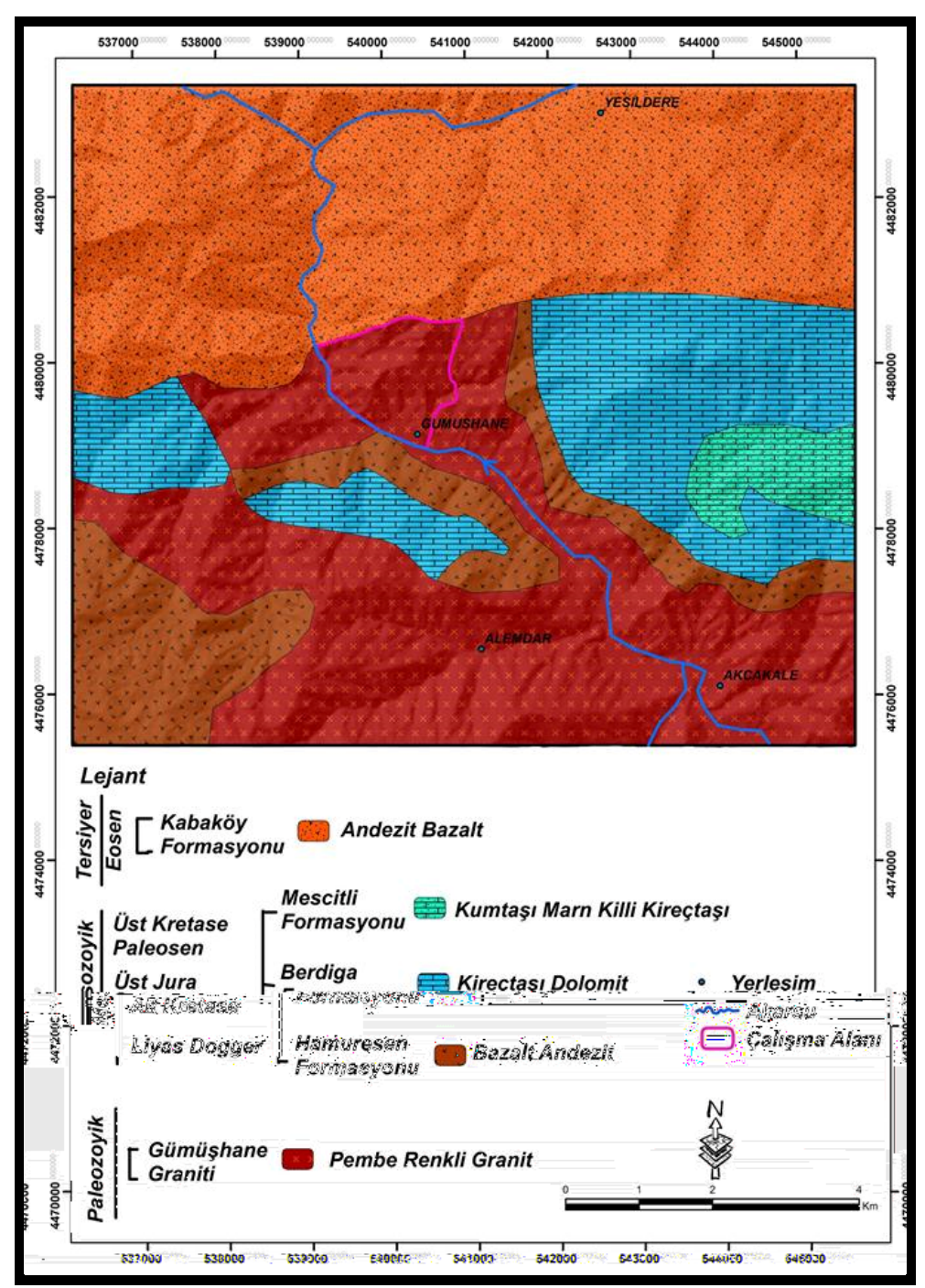

Şekil 8. Araştırma sahası litoloji haritası.

\subsubsection{Topoğrafya}

Hasanbey Mahallesi'nin kurulduğu alan yaklaşık 500 m'lik bir yükselti farkına sahiptir. Kısa mesafedeki bu yükselti farkı sebebiyle eğim değerleri yüksektir. Tepelik alanda ve vadi tabanına yakın yerlerde küçük düzlükler bulunmaktadır. Bakı haritasına baktığımızda ise mahallenin homojen bir yöney haritası olduğunu görmekteyiz. Bu sahanın akarsular tarafından çokça parçalandığını göstermektedir. Ayrıca Harşit çayının kuzeye bakan yamaçlarında bitki örtüsünün eğim bakı gibi sebeplerden dolayı gür olması sebebiyle buralarda belirgin günlenme etkisine rastlanmaz. Bitki örtüsünün günlenme süreçleri ve tor oluşumunu yavaşlattığı söylenebilir. 


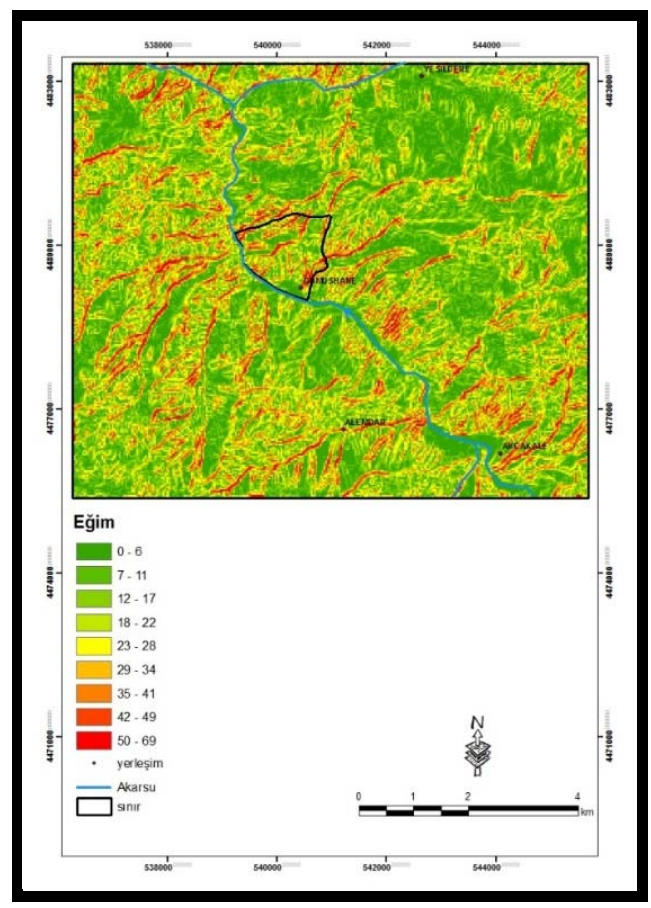

Şekil 9. Araştırma sahası eğim haritası.

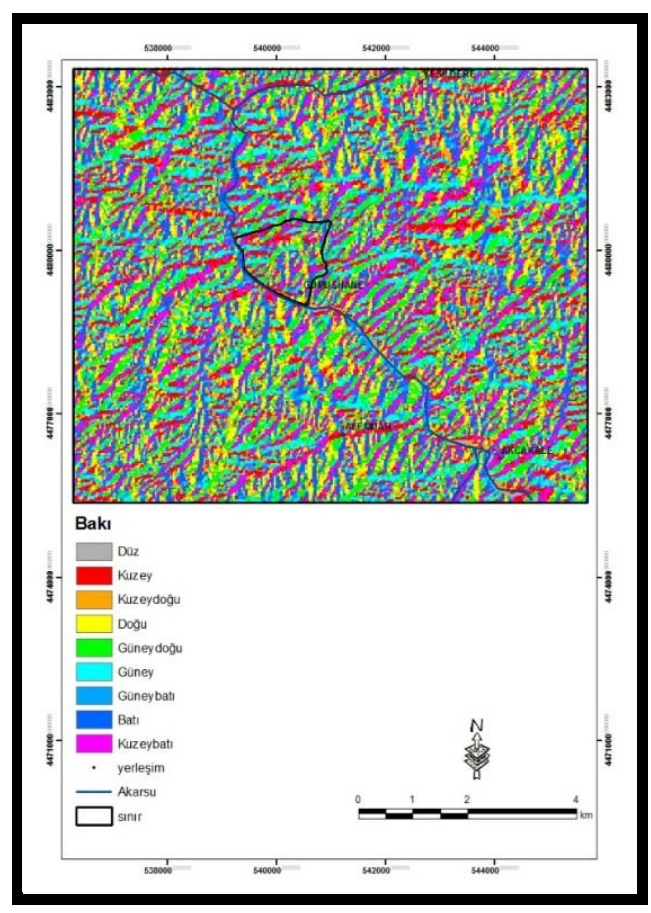

Şekil 10. Araştırma sahası bakı haritası.

\subsubsection{Morfojenez}

Araştırma sahası anakayasını granitler oluşturur. $\mathrm{Bu}$ anakayaya Gümüşhane granitleri adı verilir. Bu anakaya günlenmeye karşı oldukça duyarlı gelişmiş çatlak sistemlerine sahiptir (Foto 5).

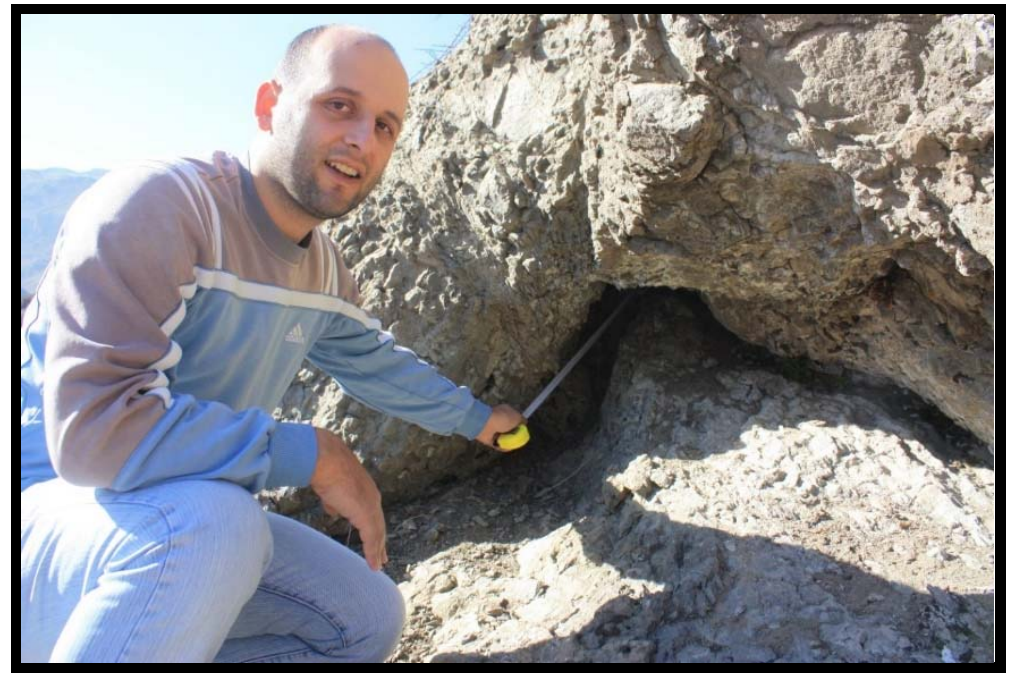

Foto 5. Anakaya üzerinde gelişen çatlak sistemlerine örnek (80 cm derinlik).

Çatlak sistemleri geliştikçe anakayadan ayrılan parçalar yamaçlarda yüzeylenmektedir. Ayrıca yer yer çatlakların büyümesi sonucu anakayadan ayrılan kaya blokları yamaçlar üzerinde anakayadan bağımsız bir şekilde görülmektedir. Araştırma sahası içerisinde verev şekilde gelişen çatlak sistemlerine bağlı olarak gelişen bazlama şeklinde torlar görülmektedir (Foto 6). Çatlak sistemlerinin gelişmesine bağlı olarak bu tor şekilleri daha da gelişerek Hasanbey Mahalesi için günümüzde olduğundan daha büyük tehlikeler oluşturacaktır. Özellikle ilkbahar aylarında artan yağışlara bağlı olarak geçirimsiz anakaya üzerinde yüzeysel akışa geçen yağmur suları yamaçlardaki moloz yığınlarını 
sürüklemektedir. Sağnak yağışlar sonrasında bu kaya parçaları yol kenarlarında, evlerin duvar kenarlarında birikmektedir.

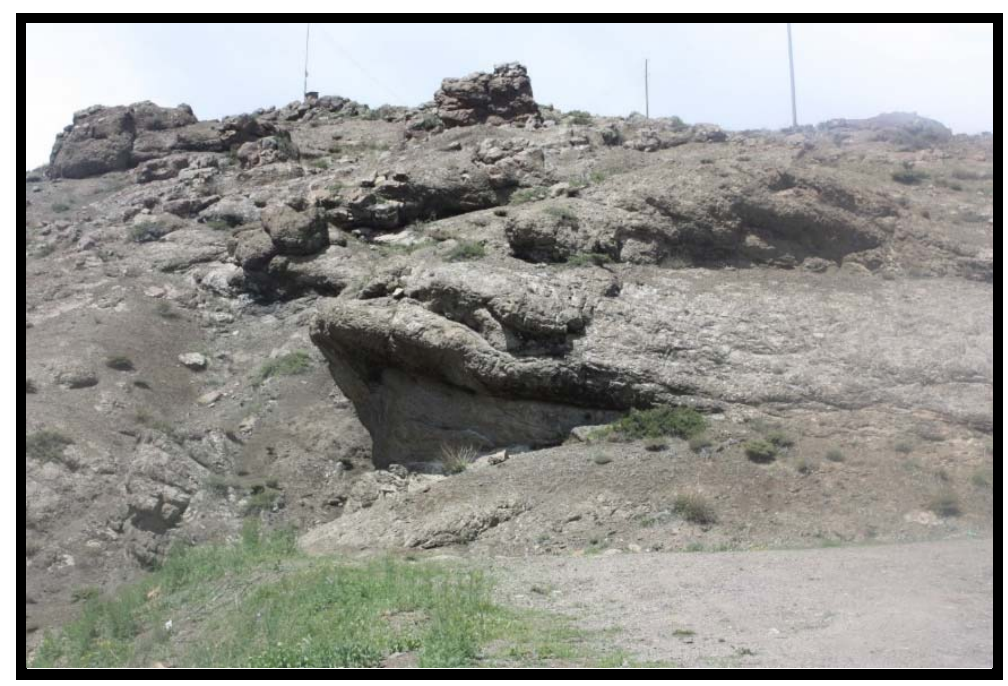

Foto 6. Bazlama şekilli tor.

\subsection{Beşerî Coğrafya Özellikleri}

\subsubsection{S Şehrin Yatay ve Dikey Büyümesindeki Gelişmeler}

Gümüşhane şehri Harşit çayının güneydoğu-kuzeybatı doğrultusunda uzanan vadisinde yaklaşık 15 km'lik bir alanda taban düzlükleri ve yamaç arazileri üzerinde kurulmuştur. Son yıllarda ise eski aşınım seviyeleri olan yüksek düzlükler üzerinde toplu konutlar, üniversite gibi yapılar inşaa edilmiştir. Gümüşhane şehir merkezi Harşit çayının özellikle kuzey yamaçlarında gelişmiş̧ir. Bunun sebebi şehrin güneybatısındaki yamaçların oldukça eğimli olmasıdır. Ayrıca Harşit çayı vadisinin batı yamaçlarındaki bu arazilerde heyelan riski de yüksektir.

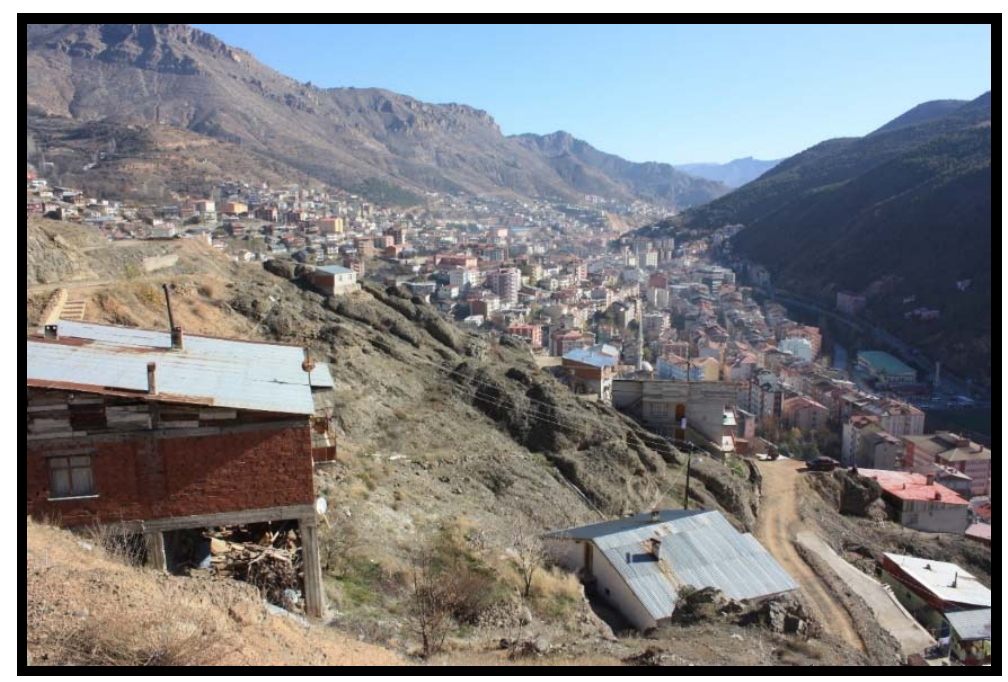

Foto 7. Gümüşhane şehrinin Hasanbey Mahallesinden görünümü.

Gümüşhane şehri Harşit çayı vadisinin kuzey yamacına yerleşmiştir. Bugünkü Gümüşhane şehrinin yerleşme çekirdeğini Hükümet Konağı'nın merkez durumda olduğu Karaer mahallesi ile Hasanbey mahallesi oluşturmaktadır 
[12]. Şehrin gelişimi Harşit çayı boyunca Trabzon ve Bayburt istikametlerine doğru devam ederken aynı zamanda dikey olarakta gelişmektedir. Dikey gelişme özellikle 1980 'den sonra nüfusun artmasının yanında yerleşim alanının kısıtlı olması ve nüfusun sosyal, kültürel ve ekonomik yapısındaki gelişmelere bağlı olarak konut inşaasında modern yapı malzemelerinin kullanılmasıyla çok katlı konut sayısının hızla artması sonucu ortaya çıkmıştır. Hasanbey Mahallesi’nin kurulmuş olduğu tepenin kuzey yamaçlarına siteler inşaa edilmektedir. Bu sitelerin inşaasında anakaya patlatılarak temel çukurları açılmakta çok katlı evler yapılmaktadır. Araştırma sahasını oluşturan Hasanbey Mahallesi'ne baktığımızda ise merkezde toplu bir yerleşme örgüsü olduğunu fakat henüz yamaçlar boyunca çok katlı evlerin yapılmadığını görüyoruz. Yüksekte kalan seyrek dokulu yerleşme görülen bu arazilerinde şehrin büyümesi karşısında daha fazla yerleşmeye açılacağı ve yüksek binalar yapılacağı kesin görülmektedir.

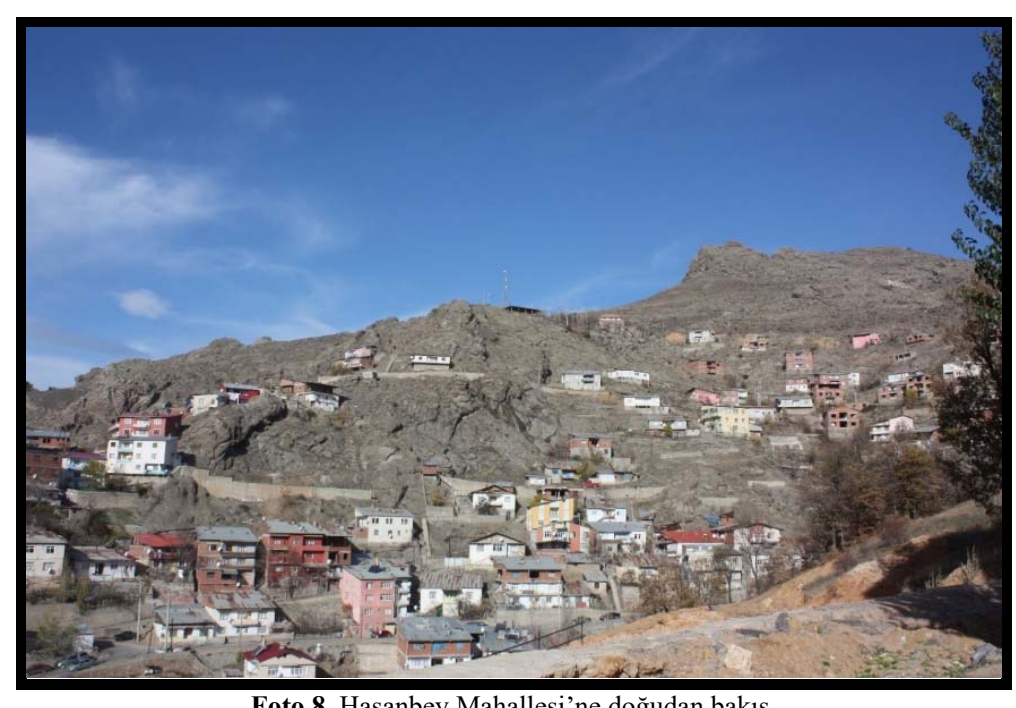

Foto 8. Hasanbey Mahallesi’ne doğudan bakış.

\subsection{Planlama-Coğrafya İlişkisi}

Planlama, bir bütünün parçası olarak doğal ortamın, olanaklarına (arazi potansiyeline) en uygun ve toplum açısından en yararlı şekilde kullanılmasını sağlamak amacı ile hazırlanan bir düzenleme ve geliştirme programıdır [13]. Yeryüzünde insanların yaşadıkları mekânları hem doğal özellikleri hem de insan faaliyetleriyle birlikte ele alarak çok yönlü bir biçimde inceleyen ve elde ettiği sonuçlara göre bu mekânlardan en iyi şekilde nasıl yararlanılabileceğini ortaya koyan coğrafya, aynı zamanda doğrudan şehir imar ve bölge planlama çalışmalarını da kapsamaktadır [14]. Ülkemizde şehirleşme ve hızlı nüfus artışı ile birlikte şehirlerde mekanın daha verimli kullanımı adeta bir zorunluluk haline gelmiştir. Özellikle gelişimi fiziki faktörlerle sınırlandırılmış ya da kesintiye uğramış şehirlerde işlevsel planlar yapılarak yeni alanlar yerleşmeye açılmalıdır.

Araştırma sahası iklim ve anakaya sebebiyle günlenme süreçlerine duyarlı bir alandır. Bu yüzden sahanın planlaması yapılırken coğrafi özellikleri göz önünde bulundurulmalıdır. Özellikle yamaç döküntülerinden kaynaklanabilecek problemlere çözüm getirilmelidir. Günlenme süreçlerine bağlı olarak sürekli gelişen yamaç döküntüleri artmaya devam etmektedir. Foto 9'da görüldüğü gibi yamaçta birikmiş moloz yığı̆ları özellikle tetikleyici kuvvetlerle, yağışla harekete geçerek yol kenarındaki park halindeki araçlara ya da yöre halkına zarar verebileceği planlama çalışmaları yapılırken dikkate alınmalıdır. 


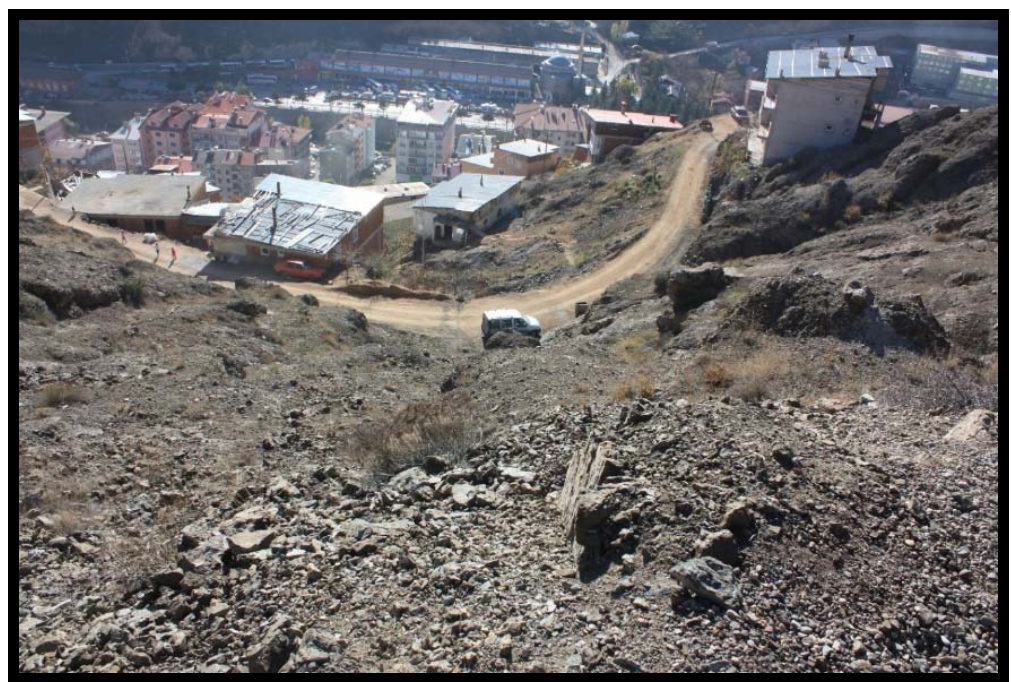

Foto 9. Hasanbey Mahallesi yüksek eğimli bir yamaçtan görüntü.

\section{SONUÇ VE TARTIŞMA}

Tor şekillerinin kurak ve yarı kurak iklim şartlarında ve granit ana kayası üzerinde geliştikleri rapor edilmiştir $[15,12,16]$. Bu çalışmada da tor şekillerinin granit anakayası üzerinde geliştiği gözlemlenmiştir.

Tor sahaları ile ilgili yapılan çalışmalar yerleşim yeri dışında kalan araziler olduğu için şekillerin yerleşme üzerindeki olumsuz etkileri konu edilmemiştir. Araştırma sahası Gümüşhane merkezinde insanların yerleştiği ve halen yaşadığı bir alandır. Burada Hasanbey Mahallesinde yaşayan insanların kendileri ve konutları açısından günlenme süreçlerinin sonuçları dikkatli değerlendirilmelidir. Özellikle planlama çalışmalarına önem verilmeli bölgede yaşayan insanların can ve mal güvenliğini riske atmadan hareket edilmelidir. Mevcut duruma müdahale edilmeksizin sürecin devam etmesi mahalle halkı için bir tehdit unsuru oluşturmaktadır. Ayrıca tor şekillerinin geliştikçe anakayadan bağımsız hale gelerek büyük kaya blokları halinde kopabileceği unutulmamalıdır. Bu yüzden yapılabilecek çalışmalar arasında;

Özellikle eğimli yamaçlar üzerinde açılan yol kenarlarında önlemler alınmalıdır,

Şekillerin gelişimine bağlı olarak ortaya çıkan taş ve moloz yığınlarının akışa geçebileceği ve insanlara zarar verebileceği düşünülmeli, bazı bölgelere istinat duvarları yapılmalıdır.

Mahallenin riskli bulunan bazı çok dik kesimlerinde püskürtme betonlar dökülerek zemin stabil hale getirilmelidir.

\section{KAYNAKÇA}

[1] SARGIN, S. 2011. Isparta Yöresinde Fiziki Coğrafya Faktörlerinin Yerleşme Birimleri Üzerindeki Etkisi, Doğu Coğrafya Dergisi, Sayı:11, Erzurum.

[2] PREECE, D. M. ve WOOD, H. R. B. 1968. The British Isles. Modern Geography Series, Book II, University Tutorial Press LTD, London.

[3] TWIDALE, C. R. 1982. Granitic Inselberg, Perspectives in Geomorphology, Edited by H.S. SHARMA, Concept's International Series In Geography, No:3. New Delhi.

[4] UZUN, A. 1995. Uludağ'da Tor Oluşumu, Türk Coğrafya Dergisi, Say1: 30, Sayfa: 53-65, İstanbul.

[5] UZUN, A., ZEYBEK, H.İ., HATİPOĞLU, İ. 2012. Bazaltik Aglomeralar Üzerinde Tor Oluşumu, Giresun, UJES 2012, III. Ulusal Jeomorfoloji Sempozyumu, Hatay. 
[6] TUNCEL, M. 1991. Türkiye'de yer değiştiren Şehirler ve Gümüşhane örneği, Geçmişte ve günümüzde Gümüşhane Sempozyumu (13-17 Haziran 1990). Syf. 29-33, Ankara.

[7] KETiN, İ. 1966, Anadolu'nun tektonik birlikleri, M.T.A. Enstitüsü Dergisi, S. 66, s.20-34.

[8] ÇOĞULU, E. 1975. Gümüşhane ve Rize Granitik Plütonların Mukayeseli Petrojeolojik ve Jeokronometrik Etüdü, Yayınlanmamış Doçençtlik Tezi, Î.T.Ü. Maden Fakültesi, İstanbul.

[9] YILMAZ, Y. 1972. Petrology and Structure of the Gümüşhane: Granite and the Surrounding Rocks,.N.E. Anatolia : $\mathrm{PhD}$. Thesis, Univ. of London, Syf. 266, London.

[10] YILMAZ, C. 1992. Kelkit (Gümüşhane) Yöresinin Stratigrafisi, Jeoloji Mühendisliği, No: 40, 50-62,1992

[11] SPARKS, B. W. 1976. Geomorphology, Longman, London.

[12] DOĞANAY, S. 2001. Gümüşhane Şehir Coğrafyası, Atatürk Üniversitesi, Sosyal Bilimler Enstitüsü, Basılmamış Doktora Tezi, Erzurum.

[13] ÜSTÜNDAĞ, Ö. ve ŞENGÜN, M.T. 2011. Türk İmar Mevzuatındaki Plan Türleri ve Fiziki Planlama - Coğrafya İlişkisi Üzerine Genel Bir Değerlendirme, Frrat Üniversitesi, Sosyal Bilimler Dergisi, Cilt: 21, Sayı:2, Sayfa:1-25 Elazı̆

[14] ÖZÇAĞLAR, A., 2006a. Coğrafyaya Giris - Sistematik, Kavramlar Yöntemler. Hilmi Usta Matbaacıllk, ISBN 975-93704-3-3, Ankara.

[15] GRESSWELL, R. K. 1968. Physical Geography, Longman.

[16] GIBBONS, C. L. M. H. 1981. Tors in Swaziland, The Geographical Journal, Vol: 147, No: 1. 
Nevşehir Bilim ve Teknoloji Dergisi (2018), 7(1) 83-99

\section{Extended Abstract}

\section{Forms Due to weathering and Their Effects on Settlement, Gümüşhane Sample Introduction}

People have begun to live together with the built-in loneliness and collective settlement has emerged. To date, Anatolia has hosted various settlements and societies due to its geographical conditions. From the most primitive to the most advanced, the ability of each settlement unit to survive depends on its success in relation to the physical environment. Cities sometimes grow and develop depending on their physical environmental conditions and functions, sometimes downsized for various reasons. In this study, it was tried to explain the development of lithology due to the weathering, and the effect of the ongoing settlement and development area of the city was emphasized. In addition to this, the forms of pressure formed on the settlement due to weathering were determined and solutions were proposed. Gümüşhane province is located in the Eastern Black Sea Region of the Black Sea Region. Hasanbey district, which forms the border of our research, and its immediate surroundings are located on the northern slopes of Harşit stream on the north east of Gümüşhane city center. The hilly area developed by the surveying tor forms includes the center of the Hasanbey district where the slopes and settlements are relatively denser.

\section{Method}

Terrestrial observations and investigations were carried out in the study, various samples were taken from the scene. Plant samples taken from the grounds were examined in the Department of Biology of Ondokuz Mayıs University together with experts and the plants were determined on species basis. In addition, various numerical and cartographic materials belonging to the area have been compiled to better explain the natural environment characteristics and some human characteristics of the area. Using the 1: 25.000 scale topography and geology maps of the research area, new maps such as digital elevation model, slope, view, geology belonging to the area were created. The creation of these maps took advantage of ArcGIS v9.3.

In order to determine the climatic characteristics of the study area, the observatory data belonging to the Gümüşhane meteorological station were used.

By evaluating the obtained data with a holistic approach, the lithological evolution was tried to be explained and the effect of the weathering on the settlement was evaluated.

\section{Results and Discussion}

The average annual temperature of the field is $9.6^{\circ} \mathrm{C}$ while the average annual rainfall is $461.1 \mathrm{~mm}$. Frost incidents occur in January and February, especially when temperatures fall below $0^{\circ} \mathrm{C}$. Physical disintegration has accelerated in recent months in connection with frost events. The maximum rainfall in the field of study falls in the spring season. This suggests that there may be more of the hazards that may occur due to precipitation in the spring months.

Lithologically, the soil has not developed, although the bedrock is suitable for crumbling and soil formation. The main reasons for this are the lack of vegetation cover and the high slope values. In relatively less sloping areas relative to the periphery, coarse-grained materials are also shallow covered so that coarse textured soils can not be seen together with the horizon.

There are not many plant varieties within the boundaries of the research area. In the field of research, the plants are confronted with small cracks in the rocks or clinging to the pieces of land in very small areas. The field is usually found in woody plants in the form of bushes such as rose hips (Rosa canina), with grassy plants.

There are Tertiary, Mesozoic and Paleozoic lands in the vicinity of the research area. All of the research area consists of Gümüşhane Granites. It has advanced crack systems that are highly susceptible to weathering. As the crack systems evolve, the parts separated from the mainland are exposed on the slopes. In addition, locally cracked rock blocks separated from the ending motherland are seen independently from the mainland on the slopes. Due to the increasing rainfall, particularly in spring, the rainwater passing over the superfluous stream on the impervious mainland drifts debris from the slopes. After heavy rains these rock fragments accumulate on the sides of the roads, on the walls of the houses.

The development of the city continues vertically along the direction of Trabzon and Bayburt along the Harşit River. Due to the social, cultural and economic developments of the vertical development population, the use of modern building materials in housing construction has resulted in a rapid increase in the number of multi-storey houses. When we look at Hasanbey district, which constitutes the research area, we see that there is a massive settlement in the center but that there are not many houses built along the slopes yet. It is certain that in the case of these high-lying sparse settlements, the city will grow more open to settlement and higher buildings will be built.

It is a field sensitive to the processes of weathering due to its climate and mainland. Therefore, geographical features should be considered when planning the site. Especially problems that can arise from slope rashes should be solved. People living in the Hasanbey district should be careful to evaluate the results of the diversion process in terms of themselves and their dwellings. Especially people who live in the region where importance is given to planning studies should be taken without risking the safety of life and property. It should also be noted that the toroidal formations can 
become independent from the motherland as they evolve and break into large rock blocks. Precautions must be taken especially on the slopes of the roads on the slopes. Resting walls must be built in some areas, where stone and debris heaps due to the development of the shapes may flow and be considered harmful to humans. The ground should be stabilized by pouring the sprayed concrete in some very steep sections of the Hasanbey district which are at risk. 